\title{
SIGHT RECORDS OF THE COMMON SCOTER IN SASKATCHEWAN
}

\author{
by Stanley D. Riome, Nipawin
}

The Common Scoter (Oidemia nigra) has been expected in Saskatchewan, but has been elusive! Dr. W. Earl Godfrey of the National Museum of Canada wrote on November 5, 1970 to Dr. C. Stuart Houston:

"The records we have of the Common Scoter in Saskatchewan prove to be either erroneous or vague. Robert Bell (1883, Proc. of the Royal Soc. of Canada, Sec. 4:49-54) wrote: 'Mr. A. S. Cochrane has brought a male scoter (Oidemia Americana Swainson), supposed to be a seacoast bird, from Reindeer Lake, in the centre of the continent.' We don't know whether the bird was on the Saskatchewan or Manitoba part of the lake but in any case the bird was very near to Saskatchewan. As there are records to the north, south, east, and west of Saskatchewan it is probably fortuitous that the bird has not been definitely known to appear in Saskatchewan occasionally."

Dr. Robert W. Nero reported the status of the Common Scoter in Birds of the Lake Athabasca region, Saskatchewan (1963:29), as follows:

"There is no known record of this species for Saskatchewan. However, in view of the taking of a specimen just over the border in Manitoba it may be well to list this bird. MacFarlane (1908-316) states that Joseph Hourston shot one on May 28,1891 , on the north end of Reindeer Lake at Lac du Brochet post (now Brochet). Brochet is located just 12 miles east of the boundary line. The species was recorded as 'fairly common' in extreme northwestern Manitoba in 1947 (Mowat and Lawrie, 1955)."

The A.O.U. Check-List, 5th edition, 1957, describes the range of the Common Scoter as:

"Winters from Kamchatka and the Komandorskie Islands to Korea, Japan and eastern China (Fukien); in America from the Pribilof and Aleutian islands to southern California; on the Great Lakes, and irregularly to Wyoming, Colorado, North Dakota, Nebraska, Kansas, Iowa, Missouri, Kentucky, Tennessee, and Louisiana; and on the Atlantic coast from Newfoundland and the Bay of Fundy south to South Carolina, rarely to Florida."

Because the occurrence of the Common Scoter in Saskatchewan had not been definitely established, I was excited to see a bird that I believed to be of this species on October 24, 1970. The day had been a fascinating one for me and my wife Gladys, since we had spent several hours observing the thousands of water birds resting on the southern reach of Tobin Lake where they enjoyed protection from hunters and the availability of nearby extensive grain fields. We then drove to the extreme northwest corner of the lake (16 $\frac{1}{2}$ miles east and 16 miles north of Nipawin) and walked carefully out to a point. There, amongst the log debris, we immediately noted four birds. Two of these were mergansers which paddled vigorously away, while a Common Loon dove and soon attained a safe distance. The fourth bird, however, seemed quite unconcerned. I quickly set up a $15 \times 60$ variable telescope on a tripod, sensing that I had never seen a bird like it before. The only certain thing was that it was a diving duck, for it soon gracefully slipped under, then surfaced nearby. A view through the telescope allowed me to make a sketch in my field note book, together with the following notation: "Quite rounded head, dark bill with nail, dark grey-brown cap and hind neck; dirty white patch on sides of face and throat; no color other than grey brown on wings; stubby tail." The bird was assumed to be a female or immature Common Scoter. Early the following morning, my son David and I attempted to return to Tobin 
Lake, but found the roads quite impassable after an all-night rain.

Seven days later, on October 31, I descended the steep eastern bank of the Saskatchewan River one mile north of Nipawin to study a raft of Lesser Scaups, and was rewarded by seeing another Common Scoter in the same plumage as the first. With the telescope it was possible to observe the following features in addition to those noted on October 24: "Belly lighter than the dark sides, back and wings; the tail projected parallel on the surface of the water and was reasonably long when seen from the side and not stubby as it appeared when seen from the rear; the tail was wagged horizontally and the neck stretched vertically several times; as the bird emerged from a dive, it seemed quite calm, while the scaups nervously raised their heads, moved them from side to side and paddled aimlessly for a few feet; the bill was quite angular on the lower edge of the lower mandible, rising sharply at its anterior $1 / 3$, the upper surface of the upper mandible was curved ..." Late in the afternoon of this day I returned with my son David and was able to locate the bird again and point out its characteristics to him.

The relative tameness of both birds, as noted above, is a characteristic of scoters. Walter H. Rich, for example, is quoted by Bent (Life histories of North American wild fowl, part 2, 1925) as saying of the scoters: "... Probably the least wary of the duck family, they may be approached quite readily ....'

I believe these two sightings were of different birds because the movement of water birds and gulls is eastward down the Saskatchewan River in the fall; the "Nipawin" bird was seen seven days later and 32 miles westward and up river from the "Tobin Lake bird. I am convinced that both were Common Scoters. The only bird with which they might have been confused is the Ruddy Duck. The fullbodied, heads-up, round-headed birds which I observed were distinctly different from the smaller, dish-billed "Andy Capp" Ruddies, with which I am thoroughly familiar.

\section{FOX PREDATION ON A BIRD ISLAND by Hans Blokpoel, Canadian Wildlife Service, Saskatoon}

This note describes Red Fox predation on colonial birds and eggs at Backes Island, Primrose Lake, Saskatchewan. The colony of White Pelicans on this island is the largest in Canada (Vermeer, 1970b).

Backes Island is a strip of boulders and gravel with a sandy shore, lying three miles off the mainland. This island is about one-half mile long; its greatest width is approximately 150 feet. The northern fifth of the island is covered with poplars and thick underbrush, the central part being mainly a bare guano-flat with some scattered tree trunks and the remainder open and covered with low shrubbery.

In 1970 Great Blue Herons were breeding in live trees at the north end of the island and in rows of dead or dying trees where the guano-flat slopes down to the lake. The pelican colony covered the guano-flat, which extended slightly into the trees. Double-crested Cormorants were found in small colonies among the pelicans, nesting on fallen trees rather than on the ground. The southern, open part of the island was occupied by gull colonies, mainly California and Ring-billed with a few Herring Gulls. Common Terns were nesting on the southernmost tip.

In late May 1970, P. P. Desfosses and J. R. Drury visited Backes Island. They counted 3,000 pelicans and reported seeing a fox. Accordingly, with the permission of T. Arsenault, Conservation Officer, Loon Lake, Saskatchewan, a five-man party led by C. W. Scott, Conservation Officer, Cold Lake, Alberta, and including myself, visited 